JIPFRI, Vol. 3 No. 2

Halaman: $108-112$

November 2019
JIPFRI (Jurnal Inovasi Pendidikan Fisika dan Riset Ilmiah)

https://doi.org/10.30599/jipfri.v3i2.455

\title{
Mikroskop Digital Berbasis Kamera Smartphone
}

\author{
Melly Ariska $^{1^{\star}}$ dan Sakinah Alawiyah ${ }^{2}$ \\ 1,2 Program Studi Pendidikan Fisika FKIP Universitas Sriwijaya \\ *E-mail: mellyariska@fkip.unsri.ac.id
}

\begin{abstract}
Abstrak
Teknologi di dunia semakin berkembang, perkembangan teknologi berdampak pada dunia pendidikan. Pemanfaatan teknologi salah satunya dengan hanphone, dimana hanphone termasuk teknologi yang sangat diminati semua orang. Maka dari itu dirancanganlah media pembelajaran mikrosksop dilengkapi kamera smartphone. Diharapkan media pembelajaran mikroskop berbasis kamera smartphone ini menjadi salah satu alternatif media pembelajaran di sekolah yang belum memiliki mikroskop cahaya. Mikroskop digital berbasis kamera smartphone ini tergolong sebagai alat laboratorium (alat praktikum) dalam pembelajaran fisika, biologi. Mikroskop berbasis kamera smartphone ini menghasilkan citra gambar yang cukup baik dan jelas, mikroskop digital berbasis kamera ini mudah dirancang dengan bahan yang mudah ditemukan dalam kehidupan sehari-hari. Cara kerja mikroskop digital berbasis kamera smartphone ini hampir sama dengan cara kerja mikroskop cahaya, hanya disini menggunakan bantuan dari smartphone sehingga citra gambar yang didapatkan lebih jelas terlihat pada layar smartphone
\end{abstract}

Kata kunci: Mikroskop digital, Smartphone, Media Pembelajaran

\begin{abstract}
Technology in the world is growing, technological developments have an impact on the world of education. One of the uses of technology is with cellphones, where cellphones are included in technology that is very popular with everyone. Therefore, the microscope media is designed with a smartphone camera. It is expected that microscope learning media based on smartphone cameras is one of the alternative learning media in schools that do not have a light microscope. The smartphone camera-based digital microscope is classified as a laboratory tool (tool of practice) in learning physics, biology. This smartphone camera-based microscope produces a fairly good and clear image, this camera-based digital microscope is easily poisoned with material that is easily found in everyday life. The workings of a digital microscope based on a smartphone camera are almost the same as the way a light microscope works, only here use the help of a smartphone so that the image obtained is more clearly visible on the smartphone screen.
\end{abstract}

Keywords: digital microscope, smartphone, learning media

\section{PENDAHULUAN}

Perkembangan teknologi di dunia semakin pesat, perkembangan ini berdampak pada salah satu bidang pendidikan. Khususnya pendidikan Fisika, saat ini peserta didik lebih ditekankan untuk melek teknologi untuk menghadapi era revolusi Industri 4.0, seperti penggunaan Komputasi dalam pembelajaran fisika. (Ariska,2019). Pembelajaran fisika akan lebih mudah dipahami jika didampingi dengan media yang menarik dalam proses pembelajaran. Pendidikan saat ini sangat minim penggunaan media di dalam pembelajaran, sedangkan media sangat dibutuhkan dalam pembelajaran (Ariska, 2018). Media merupakan salah satu komponen dalam kegiatan pembelajaran yang membuat pembelajaran mencapai tujuan pembelajaran. Beberapa sekolah bahkan tidak punya alat peraga yang lengkap (Kosasih, Hasiholan, \& Cahyo, 2018). Mengingat pentingnya peranan media pembelajaran sebagai alat bantu dalam kegiatan belajar mengajar, yakni berupa sarana yang dapat memberikan pengalaman visual 
kepada peserta didik dalam merangsang motivasi belajar peserta didik, memperjelas dan mempermudah konsep yang kompleks dan abstrak menjadi lebih sederhana, konkrit serta mudah dipahami. Untuk mencapai tujuan pembelajaran, maka guru dituntut mampu menggunakan alat-alat bantu yang tersedia. Jika belum tersedia, guru dituntut harus mampu mengembangkan keterampilan membuat media pembelajaran yang akan digunakan (Arianti, 2014). Salah satu media yang digunakan dalam pembelajaran IPA adalah mikroskop.

Mikroskop merupakan alat bantu yang digunakan untuk melakukan pengamatan dan penelitian, karena dapat digunakan untuk melihat objek pengamatan yang kecil terlihat besar. Mikroskop ini gabungan dari dua lensa optik yaitu lensa cembung sebagai lensa positif disebut lensa okuler dan lensa objektif. Mikroskop termasuk dalam jenis alat optik. Alat optik banyak digunakan dalam kehidupan sehari - hari. Seperti kacamata, spion, kamera, teleskop dan lain-lain. Salah satu bentuk mikroskop adalah mikroskop digital. Mikroskop digital menghasilkan gambar dalam bentuk pengolahan citra digital bertujuan untuk melakukan perhitungan terhadap data dalam angka yang mewakili aras keabuan (citra hitam putih) atau koordinat warna (citra berwarna) untuk berbagai tujuan, misalnya untuk peningkatan mutu citra (Raya, 2013).

Akibat kondisi keterbatasan alat pembelajaran ini, maka guru dituntut mempunyai kreativitas merakit media pembelajaran apabila belum tersedia. Sebagai alternatif pengganti mikroskop yang begitu mahal sehingga perlu dibuat mikroskop sederhana yang tidak membutuhkan banyak biaya, salah satunya adalah mikroskop digital sederhana yang memanfaatkan Smartphone.

Berdasarkan uraian diatas, maka peneliti berinovasi merancang mikroskop digital berbasis kamera Smartphone sebagai alternatif media pembelajaran fisika di sekolah.

\section{METODE/EKSPERIMEN}
Alat dan Bahan
1. Lensa pointer
2. Led
3. Akrilik
4. Mistar
5. Smartphone
6. Baut dan Mur

\section{Rancangan Alat}

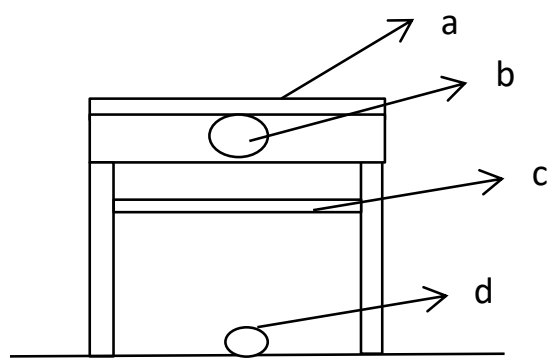

Gambar 1. Rancangan Mikroskop berbasis smartphone

Keterangan:

a. Dudukan kamera

b. Tempat lensa okuler

c. Tempat objek

d. Pencahayaan/ senter

\section{HASIL DAN PEMBAHASAN}

\section{Pengujian}

Pada tahap pengujian dilakukan beberapa uji coba menggunakan mikroskop sederhana berbasis kamera. Uji coba ini meliputi hasil pengamat menggunakan mikroskop sederhana berbasis kamera, dan perbandingan dengan mikroskop manual.

\section{Pengujian hasil pengamatan}

Hasil yang didapatkan oleh mikroskop sederhana berbasis kamera untuk beberapa objek/sampel, diantaranya batang genjer. Berikut hasil pengamatan perbesaran dengan menggunakan mikroskop sederhana berbasis kamera dengan perbesaran sebanyak 3 kali.

Bayangan benda yang dibentuk oleh lensa ada kemungkinan diperbesar atau diperkecil dibandingkan dengan benda atau objek aslinya. Dalam hal ini, dikenal adanya perbesaran (magnification). Pengertian 
perbesaran bayangan pada lensa sama dengan pengertian perbesaran bayangan pada cermin lengkung yaitu lensa cembung dan lensa cekung. Perbesaran bayangan didefinisikan sebagai perbandingan antara tinggi bayangan dan tinggi benda atau jarak bayangan terhadap lensa dan jarak benda ke lensa (Prihatiningtya, 2013). Untuk mendapatkan rumus perbesaran bayangan, perhatikan bagan berikut ini:

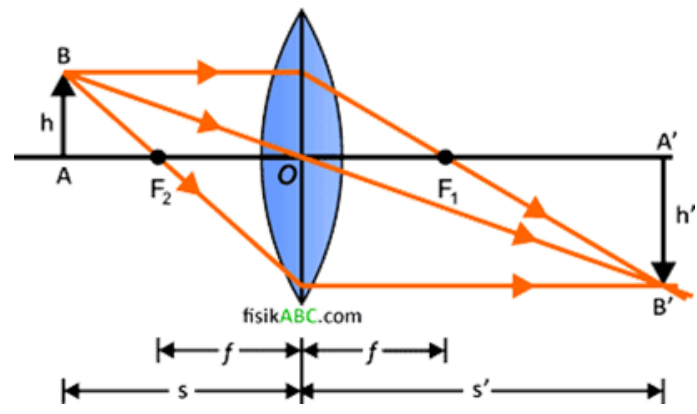

Gambar 2. Bayangan pada lensa cembung

Dari gambar bayangan pada lensa cembung di atas, kita ketahui bahwa:

\section{$\triangle \mathrm{AOB} \sim \triangle \mathrm{A}^{\prime} \mathrm{OB}^{\prime}$}

Sehingga:

$$
\begin{aligned}
& A^{\prime} B^{\prime}: A B=A^{\prime} O: A O \\
& h^{\prime}: h=s^{\prime}: s \\
& h^{\prime} / h=s^{\prime} / s
\end{aligned}
$$

Dengan demikian, perbesaran bayangan pada lensa, baik pada lensa cembung maupun cekung, di rumuskan sebagai berikut.

$$
M=\left|\begin{array}{l|l|}
h^{\prime} \\
\end{array}\right|=\mid \begin{aligned}
& \mathrm{s}^{\prime} \\
&
\end{aligned}
$$

Keterangan:

$\mathrm{h}^{\prime}=$ tinggi bayangan

$\mathrm{h}=$ tinggi benda

$\mathrm{s}^{\prime}=$ jarak bayangan

Kemungkinan-kemungkinan dari rumus perbesaran di atas

1. Jika $M>1$ atau $s^{\prime}>s$ maka bayangan diperbesar

2. Jika $\mathrm{M}=1$ atau s' = s maka bayangan sama besar

3. Jika $M<1$ atau $s^{\prime}<s$ maka bayangan diperkecil

Pada lensa cembung, harga jarak fokus (f) selalu positif hal ini dikarenakan titik fokus aktif lensa cembung merupakan titik fokus sejati. Dinamakan titik fokus sejati karena terbentuk dari perpotongan sinar-sinar bias di belakang lensa yang berasal dari sinar-sinar datang sejajar sumbu utama. Dengan kata lain, titik fokus aktif lensa cembung berada di belakang lensa. Sedangkan pada lensa cekung, harga jarak fokus (f) selalu negatif hal ini dikarenakan titik fokus aktif lensa cekung merupakan titik fokus maya. Disebut titik fokus maya karena terbentuk dari perpotongan perpanjangan sinar-sinar bias di di depan lensa yang berasal dari sinar-sinar datang sejajar sumbu utama. Dengan kata lain, fokus aktif lensa cekung berada di depan lensa (Tipler, 2001).

Harga jarak bayangan (s') pada lensa cembung dan cekung memiliki karakteristik yang berbeda. Pada lensa cembung, harga s' bisa saja positif atau negatif. Jika bayangan terletak di belakang lensa maka s' bernilai posistif dan bayangan bersifat nyata, terbalik. Sedangkan apabila bayangan terletak di depan lensa cembung, maka s' bernilai negatif dan bayangan bersifat maya, tegak. Namun, pada lensa cekung letak bayangan selalu di depan lensa sehingga s' selalu berharga negatif dengan sifat bayangan yang terbentuk adalah maya, tegak, diperkecil (Kim, 2016).

Lensa yang umumnya kita kita kenal ada dua jenis, yaitu lensa cembung (lensa konvergen) dan lensa cekung (lensa divergen). Keduanya memiliki sifat dan karakteristik yang berbeda. Namun, pada kesempatan kali ini kita tidak akan membicarakan lebih jauh mengenai lensa cembung maupun lensa cekung, karena kita akan membahas dua rumus penting pada lensa yaitu rumus perbesaran bayangan dan rumus kekuatan lensa (Skandarajah, 2014).

Tabel 1. Hasil Pengamatan dengan mikroskop dan Mikroskop berbasis Android

\begin{tabular}{ccc}
\hline & Mikroskop & Mikroskop \\
analog & berbasis \\
smartphone
\end{tabular}

$1 \mathrm{X}$

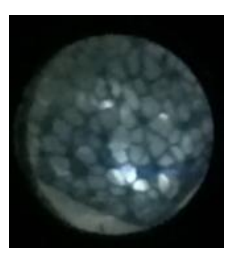




\begin{tabular}{ccc}
\hline M & $\begin{array}{c}\text { Mikroskop } \\
\text { analog }\end{array}$ & $\begin{array}{c}\text { Mikroskop } \\
\text { berbasis } \\
\text { smartphone }\end{array}$ \\
\hline
\end{tabular}

$2 X$
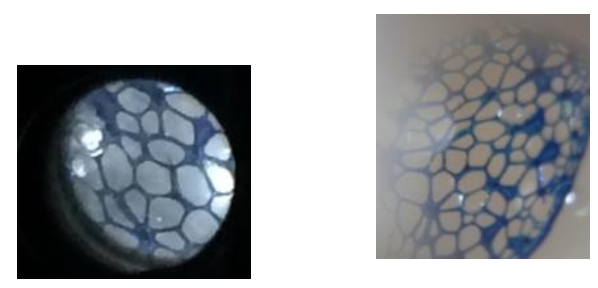

$3 X$
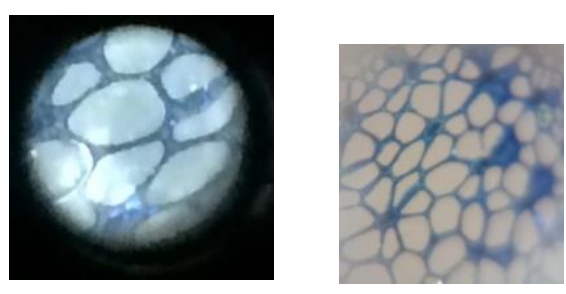

Dari data tabel 1 di atas perbandingan citra hasil perbesaran dari kedua mikroskop digital berbasis smartphone dengan mikroskop analog dalam pengamatan pada objek batang genjer dan gula. Perbesaran yang dihasilkan sesuai dengan pembentukan bayangan dari mikroskop analog, yang menggunakan dua lensa cembung menghasilkan sifat bayangan nyata, terbalik dan diperbesar. Lalu hasil dari mikroskop digital berbasis smartphone lebih jelas dan terlihat lebih detail jika dibandingkan dengan mikroskop analog. Hal ini disebabkan sumber pencahayaan berbeda, pada mikroskop berbasis smartphone mendapatkan cahaya dari lampu LED atau senter sedangkan untuk mikroskop analog itu mendapatkan cahaya dari sinar matahari.

Mikroskop digital sederhana ini menggunakan lensa laser pointer sebagai lensa objektif dengan menggunakan kamera smartphone (Pengganti lensa mata). Untuk membuat mikroskop digital berbasis kamera smartphone sangat sederhana dengan bahan yang sangatlah mudah ditemukan dengan biaya yang murah. Dibandingkan dengan mikroskop digital aslinya, mikroskop digital sederhana di desain Se-sederhana mungkin sehingga mudah digunakan sebagai media pembelajaran bidang studi fisika dan biologi.

Berdasarkan data yang didapatkan dari perbandingan mikroskop digital berbasis kamera dan miksroskop analog, bahwa mikroskop digital berbasis kamera ini efektif untuk dijadikan sebagai alternatif media pembelajaran di sekolah yang belum lengkap. Media mikroskop sederhana yang dikembangkan memiliki kelebihan dan kekurangan. Kelebihan mikroskop sederhana antara lain terbuat dari bahan yang mudah diperoleh dari lingkungan sekitar, proses pembuatannya tidak sulit sehingga peserta didik dapat membuatnya sendiri. Kekurangan mikroskop sederhana adalah hanya mampu melihat obyek dengan perbesaran 20 kali dari ukuran sebenarnya lalu kualitas yang dihasilkan juga sesuai dengan kualitas kamera smartphone yang digunakan (Hartati, 2013).

\section{PENUTUP}

Dari uraian pembahasan di atas kesimpulan yang diperoleh yaitu alat mikroskop digital sederhana berbasis kamera smartphone dapat menghasilkan citra gambar yang lumayan baik dengan perbesaran dari smartphone. Perbesaran yang dihasilkan sesuai dengan pembentukan bayangan dari mikroskop analog yang menggunakan dua lensa cembung menghasilkan sifat bayangan nyata, terbalik dan diperbesar. Lalu hasil dari mikroskop digital berbasis smartphone lebih jelas dan terlihat lebih detail jika dibandingkan dengan mikroskop analog. Diharapkan dapat bermanfaat untuk pembelajaran fisika. Kelebihan mikroskop sederhana antara lain terbuat dari bahan yang mudah diperoleh dari lingkungan sekitar, proses pembuatannya tidak sulit sehingga peserta didik membuatnya sendiri. Kekurangan mikroskop sederhana adalah hanya mampu melihat obyek dengan perbesaran 20 kali dari ukuran sebenarnya lalu kualitas yang dihasilkan juga sesuai dengan kualitas kamera smartphone yang digunakan.

\section{REFERENSI}

Arianti, E. (2014). Mikroskop Sederhana Dari Botol Plastik Sebagai Alat Pembelajaran Pada Pengamatan Sel. Jurnal Edubio Tropika, 2(2).

Ariska, M., Akhsan, H., \& Zulherman, Z. (2018). Utilization of Maple-based Physics 
Computation in Determining the Dynamics of Tippe Top. Jurnal Penelitian Fisika dan Aplikasinya (JPFA), 8(2), 123-131. http://dx.doi.org/10.26740/jpfa.v8n2.p1 23-131.

Ariska, M. (2018). Analisis Momen Inersia Tippe Top Di Bidang Datar Sebagai Kontribusi Pada Mata Kuliah Mekanika. Jurnal Inovasi dan Pembelajaran Fisika, 5(2), 181-186. https://doi.org/10.36706/jipf.v5i2.7316.

Hartati, S., Harjoko, A., \& Supardi, T. W. (2013). The digital microscope and its image processing utility. TELKOMNIKA (Telecommunication Computing Electronics and Control), 9(3), 565574.

Kim, H., Gerber, L. C., Chiu, D., Lee, S. A., Cira, N. J., Xia, S. Y., \& Riedel-Kruse, I. H. (2016). Correction: LudusScope: Accessible Interactive Smartphone Microscopy for Life-Science Education. Plos one, 11(12), e0168053.

Prihatiningtyas, S., Prastowo, T., \& Jatmiko, B. (2013). Imlementasi Simulasi PhET dan Kit Sederhana untuk Mengajarkan Keterampilan Psikomotor Siswa padaPokok Bahasan Alat Optik. Jurnal Pendidikan IPA Indonesia, 2(1). https://doi.org/10.15294/jpii.v2i1.2505.

Raya, A. S., Hidayatno, A., \& Zahra, A. A. (2013). Modifikasi Mikroskop Dengan Perbesaran Digital Menggunakan Sistem Kamera. Transient, 2(3), 728733.

Skandarajah, A., Reber, C. D., Switz, N. A., \& Fletcher, D. A. (2014). Quantitative imaging with a mobile phone microscope. PloS one, 9(5), e96906.

Tipler, p. (2001). Fisika untuk sains dan teknik edisi ketiga jilid 2. Jakarta: Erlangga 